\title{
Aplikasi Jenis Pupuk organik terhadap Kadar Hara NPK dan Produksi Kedelai (Glycine max (L.) Merril) pada Jarak Tanam yang Berbeda di Lahan Pasang Surut
}

\author{
Application of Organic Fertilizer Types to NPK Nutrients Levels and Soybeans Production \\ (Glycine max (L.) Merril) at Different planting Spaces in Tidal Land \\ Neni Marlina ${ }^{1 *}$, Iin Siti Aminah ${ }^{2}$, Nurbaiti Amir ${ }^{2}$, Rosmiah Rosmiah ${ }^{2}$ \\ ${ }^{1}$ Fakultas Pertanian, Universitas Palembang, Sumatera Selatan 30139 \\ ${ }^{2}$ Fakultas Pertanian, Universitas Muhammadiyah Palembang, Sumatera Selatan 30116 \\ ${ }^{*}$ Penulis untuk korespondensi: marlina002@yahoo.com \\ (diterima 12 Juni 2019, disetujui 16 Juli 2019)
}

\begin{abstract}
Sitasi: Marlina N, Aminah IS, Amir N, Rosmiah R. 2019. Application of organic fertilizer types to NPK nutrients levels and soybeans production (Glycine max (L.) Merril) at different planting spaces in tidal land. Jurnal Lahan Suboptimal: Journal of Suboptimal Lands. 8(2): 148-158.
\end{abstract}

\begin{abstract}
Tidal lowlands flood type $\mathrm{C}$ is suboptimal land and very potential in cultivating soybean, but it has problems in soil fertility, macro and micro nutrient poor, therefore to increase soil fertility can be given various types of organic fertilizers, including cow manure organic fertilizer, chicken manure organic fertilizer and biofertilizer. All types of organic fertilizers are composted, and specifically biofertilizers are made with their own formula. It is expected that the organic fertilizer provided can increase soil fertility and nutrient availability for soybean plants. This study aimed to get the best type of organic fertilizer on the availability of nutrient levels of NPK and soybean production at different spacing in tidal land. This research was conducted in Jaya Agung Village, Lalan District, Musi Banyuasin Regency, South Sumatra Province, and was carried out in March 2018 June 2018. The method used was the experimental method. The design used is a split-plot design. with 9 treatment combinations and repeated 3 times. As the main plot treatment is plant spacing $(20 \mathrm{~cm} \times 20 \mathrm{~cm}, 20 \mathrm{~cm} \times 30 \mathrm{~cm}$ and $20 \mathrm{~cm} \mathrm{x} 40 \mathrm{~cm})$, and treatment of subplots are: types of cow manure organic fertilizers 10 ton/ha, chicken manure organic fertilizer $10 \mathrm{ton} / \mathrm{ha}$, and biofertilizer $400 \mathrm{~kg} / \mathrm{ha}$. The results showed that the combination treatment of plant spacing of $20 \mathrm{~cm}$ x $30 \mathrm{~cm}$ with the type of biofertilizer $400 \mathrm{~kg} / \mathrm{ha}$ could increase soybean production by $9.11 \mathrm{~g} /$ plot or equivalent to 2.43 ton/ha.
\end{abstract}

Keywords: soybeans, organic fertilizer, tidal land flood type $\mathrm{C}$, plant spacing

\begin{abstract}
ABSTRAK
Lahan pasang surut tipe luapan $\mathrm{C}$ merupakan lahan suboptimal dan sangat berpotensi dalam pengembangan tanaman kedelai, namun lahan pasang surut mempunyai kendala dalam kesuburan tanah, miskin hara makro dan mikro, oleh karena itu untuk meningkatkan kesuburan tanahnya dapat diberi berbagai jenis pupuk organik, diantaranya pupuk organik kotoran sapi, pupuk organik kotoran ayam dan pupuk organik hayati. Jenis pupuk organik ini dikomposkan semua, dan khusus pupuk organik hayati dibuat dengan formula sendiri. Diharapkan pupuk organik yang diberikan dapat meningkatkan kesuburan tanah dan
\end{abstract}


ketersediaan unsur hara bagi tanaman kedelai. Penelitian ini bertujuan untuk mendapatkan jenis pupuk organik yang terbaik terhadap ketersediaan kadar hara NPK dan produksi kedelai pada jarak tanam yang berbeda di lahan pasang surut. Penelitian ini dilaksanakan di Desa Jaya Agung, Kecamatan Lalan Kabupaten Musi Banyuasin Provinsi Sumatera Selatan, dan di laksanakan pada bulan Maret 2018-Juni 2018. Metode yang dilakukan metode experimen. Rancangan yang digunakan rancangan petak terbagi (Split-plot). dengan 9 kombinasi perlakuan dan diulang sebanyak 3 kali. Sebagai perlakuan petak utama adalah jarak tanam $(20 \mathrm{~cm} \times 20 \mathrm{~cm}, 20 \mathrm{~cm} \times 30 \mathrm{~cm}$ dan $20 \mathrm{~cm} \times 40 \mathrm{~cm})$, dan perlakuan anak petak adalah: jenis pupuk organik (pupuk organik kotoran sapi 10 ton/ha, pupuk organik kotoran ayam 10 ton/ha, dan pupuk organik hayati $400 \mathrm{~kg} / \mathrm{ha}$. Hasil penelitian menunjukkan bahwa perlakuan kombinasi antara jarak tanam $20 \mathrm{~cm}$ x $30 \mathrm{~cm}$ dengan jenis pupuk organik hayati $400 \mathrm{~kg} / \mathrm{ha}$ mampu meningkatkan produksi kedelai 9,11 g/petak atau setara dengan 2,43 ton/ha.

Kata kunci: kedelai, pupuk organik, lahan pasang surut tipe luapan C, jarak tanam

\section{PENDAHULUAN}

Produksi tanaman kedelai terus meningkat dari tahun 2013 sampai tahun 2016 yaitu dari 5.14 ton sampai 23.39 ton hektar, namun pada tahun 2017 terjadi penurunan yaitu sebesar $49.59 \%$ yaitu hanya 11.79 ton (BPS, 2019). Salah satu kurangnya produksi kedelai di Indonesia disebabkan karena harga panen tanaman kedelai tidak stabil dan cenderung merugikan petani dan membuat petani kurang bergairah untuk menanam kedelai lagi dan mengakibatkan telah berkurangannya luas lahan untuk penanaman kedelai dari 1.2 juta hektar menjadi 500 ribu hektar (Detik Finance, 2013).

Kebutuhan kedelai di Indonesia setiap tahun terus meningkat dengan pertambahan penduduk dan perbaikan pendapatan per kapita, oleh karena itu diperlukan suplai kedelai tambahan yang harus diimpor, karena produksi dalam negeri belum dapat mencukupi kebutuhan tersebut. Salah satu pencapaian usaha tersebut diperlukan perluasan lahan diantarnya lahan pasang surut. Pemanfaatan lahan pasang surut tipe luapan $\mathrm{C}$ merupakan salah satu strategi untuk mengatasi semakin terbatasnya lahan subur untuk pertanian terutama di Sumatera. Sumatera memiliki luas lahan pasang surut 7.147 ribu hektar untuk pertanian, namun baru sekitar 3.927 ribu hektar yang telah dibuka (Nugroho et al.
(1993) dalam Suriadikarti dan Sutriadi (2007). Luas lahan pasang surut ini termasuk daerah Sumatera Selatan yang sebagian besar di daerah Banyuasin. Lahan pasang surut memiliki potensi yang besar untuk ditanami tanaman kedelai, walaupun menghadapi berbagai permasalahan. Menurut Hutahean et al. (2019) lahan pasang surut dihadapkan pada keragaman sifat fisiko kimia lahan berupa kesuburan dan $\mathrm{pH}$ tanah yang rendah, zat beracun (Al, besi, hidrogen sulfida dan natrium).

Perbaikan kesuburan tanah di lahan pasang surut dapat menggunakan pupuk organik dan penggunaan jarak tanam yang cocok. Pupuk organik yang digunakan pada penelitian ini adalah pupuk kandang kotoran ayam, pupuk kandang kotoran sapi dan pupuk organik hayati. Pupuk organik berupa pupuk kandang kotoran ayam dan sapi ini banyak tersedia di daerah sekitar lahan pasang surut dan harganya murah. Khusus pupuk organik hayati ini dibuat dengan menggunakan pupuk kandang kotoran ayam yang diperkaya bakteri penambat $\mathrm{N}_{2}$ dan bakteri pelarut fosfat. Diharapkan pemberian jenis pupuk organik ini dapat memperbaiki sifat fisik, sifat kimia dan sifat biologi tanah dan selanjutnya dapat menyumbangkan unsur hara dan meningkatkan produksi tanaman kedelai.

Hasil penelitian Marlina et al. (2015), menunjukkan bahwa perlakuan jenis pupuk organik kotoran ayam 10 ton/ha mampu 
meningkatkan pertumbuhan dan produksi tanaman kacang tanah sebesar 2.73 kg/petak. Dilanjutkan Marlina et al. (2017, 2018) bahwa perlakuan jenis pupuk organik hayati yang diperkaya bakteri Azospirillum dan bakteri pelarut fosfat sebanyak 400 $\mathrm{kg} / \mathrm{ha}$ dan $25 \%$ pupuk anorganik mampu meningkatkan produksi padi dan bawang merah sebesar $0,91 \mathrm{~kg} /$ petak dan 85.33 g/rumpun.

Pengaturan jarak tanam dengan kepadatan tertentu bertujuan memberi ruang tumbuh pada tanaman agar tumbuh dengan baik. Jarak tanam akan mempengaruhi kepadatan dan efisiensi penggunaan cahaya, persaingan di antara tanaman dalam penggunaan air dan unsur hara sehingga akan mempengaruhi produksi tanaman (Hidayat, 2008). Hasil penelitian Sutrisno dan Titiek (2004), menunjukkan bahwa perlakuan jarak tanam $20 \mathrm{~cm}$ x $30 \mathrm{~cm}$ menghasilkan jumlah polong paling banyak yaitu 21.25 polong. Tujuan penelitian ini untuk mendapatkan kadar hara NPK dan produksi kedelai (Glycine max (L.) Merrill) yang diaplikasi jenis pupuk organik pada jarak tanam yang berbeda di lahan pasang surut tipe luapan $\mathrm{C}$.

\section{BAHAN DAN METODE}

Penelitian ini dilaksanakan di Desa Jaya Agung, Kecamatan Lalan Kabupaten Musi Banyuasin Provinsi Sumatera Selatan, dan di laksanakan pada bulan Maret 2018 - Juni 2018. Metode yang dilakukan metode experiment di lapangan. Rancangan yang digunakan rancangan petak terbagi (Splitplot). dengan 9 kombinasi perlakuan dan diulang sebanyak 3 kali. Sebagai perlakuan petak utama adalah jarak tanam $(20 \mathrm{~cm}$ x 20 $\mathrm{cm}, 20 \mathrm{~cm} \times 30 \mathrm{~cm}$ dan $20 \mathrm{~cm} \times 40 \mathrm{~cm}$ ), dan perlakuan anak petak adalah: jenis pupuk organik (pupuk organik kotoran sapi 10 ton/ha, pupuk organik kotoran ayam 10 ton/ha, dan pupuk organik hayati $400 \mathrm{~kg} / \mathrm{ha}$. Uji lanjut yang digunakan adalah Uji BNJ dengan menggunakan program SAS 9.1.3 Portable.

\section{Cara Kerja}

\section{Pupuk Organik Hayati}

Formula pupuk hayati terdiri dari pupuk kandang kotoran ayam dengan dedak (10:1) dikomposkan selama 1 bulan, disterilisasikan kemudian baru diperkaya bakteri penambat $\mathrm{N}_{2}$ (Azospirillum) dan bakteri pelarut fosfat.

\section{Pembukaan dan Persiapan Lahan}

Lahan dibersihkan dari vegetasi yang ada untuk memudahkan dalam pengolahan lahan. Pengolahan tanah dilakukan dengan pencangkulan manual. Setelah itu dibuat petakan dengan ukuran $1 \mathrm{~m}$ x $3 \mathrm{~m}$ sebanyak 27 petakan, dengan jarak antar petakan $50 \mathrm{~cm}$ dan jarak antar ulangan 100 $\mathrm{cm}$.

\section{Aplikasi Pupuk Organik}

Pengaplikasian pupuk organik (kotoran ayam, kotoran sapi dan pupuk organik hayati) dilakukan setelah pembukaan lahan selama 1 minggu yaitu, Pupuk organik kotoran sapi dengan dosis 10 ton/ha atau 3 $\mathrm{kg} /$ petak, Pupuk organik kotoran ayam dengan dosis 10 ton/ha atau $3 \mathrm{~kg} /$ petak, Pupuk organik hayati dengan dosis 400 $\mathrm{kg} / \mathrm{ha}$ atau $120 \mathrm{~g} /$ petak.

\section{Penanaman}

Penanaman dilakukan dengan cara dibuat lubang tanam sedalam $3 \mathrm{~cm}$ dengan cara ditugal. Setiap lubang tanam dimasukkan tiga benih Kedelai, lalu ditutup dengan tanah dengan jarak tanam $20 \mathrm{~cm} \mathrm{x}$ $20 \mathrm{~cm}, 20 \mathrm{~cm}$ x $30 \mathrm{~cm}$, dan $20 \mathrm{~cm}$ x $40 \mathrm{~cm}$.

\section{Pemeliharaan}

Pemeliharaan tanaman Kedelai meliputi; (1) Penyiraman, penyiraman dua kali sehari yaitu pada pagi dan sore hari. (2) Penjarangan, penjarangan dilakukan satu minggu setelah tanam. (3) Penyiangan, penyiangan pertama, dilakukan waktu tanaman berumur 2-4 minggu setelah tanam. Penyiangan kedua, dilakukan setelah tanaman selesai berbunga, yakni pada umur sekitar 45-60 hari setelah tanam. 
Penyiangan ketiga, perlu dilakukan bila tampak banyak gulma yang tumbuh. Penyiangan yang dilakukan dilapangan yaitu dengan cara mencabut. (4) Pembumbunan, pembumbunan dilakukan setelah tanaman berumur 3-4 minggu setelah tanam. Cara pembumbunan adalah dengan meninggikan tanah disekeliling deretan tanaman Kedelai, membentuk suatu guludan. (5) Pengendalian hama dan penyakit, pengendalian hama dilakukan dengan menyemprotkan pada tanaman menggunakan insektisida Sidametrin 50 EC.

\section{Panen}

Panen dilakukan 90 hari setelah tanaman dengan menempuh kriteria panen fisiologis yaitu sebagian besar daun sudah menguning, tetapi bukan karena serangan hama atau penyakit, lalu gugur, buah mulai berubah warna dari hijau menjadi kuning kecoklatan dan retak-retak, atau polong sudah kelihatan tua, batang berwarna kuning agak coklat dan gundul dengan mencabut atau memotong tanaman contoh setiap perlakuan.

\section{Peubah yang diamati.}

Meliputi tinggi tanaman $(\mathrm{cm})$, jumlah cabang primer (cabang), jumlah polong per tanaman (polong), jumlah polong hampa (polong), serapan hara $\mathrm{N}, \mathrm{P}$ dan $\mathrm{K}$, berat 100 biji (g), jumlah biji per polong (buah) dan Hasil panen per petak.

\section{HASIL DAN PEMBAHASAN}

Hasil analisa tanah sebelum penelitian menunjukkan bahwa tanah ni tergolong sangat masam $\left(\mathrm{pH} \quad \mathrm{H}_{2} \mathrm{O}=4.23\right)$ dengan kapasitas tukar kation tergolong tinggi (25.00 $\mathrm{cmol}_{(+)} / \mathrm{kg}$ ), kandungan C-organik $3.83 \%$ tergolong sangat tinggi, kandungan $\mathrm{N}$-total tergolong rendah $(0.32 \%)$ dan $\mathrm{P}$ Bray tergolong tinggi $(10.42 \mathrm{mg} / \mathrm{kg})$, basa tertukar seperti Ca-dd $1.86 \quad \mathrm{cmol}_{(+)} / \mathrm{kg}$ tergolong sangat rendah, $\mathrm{Mg}$-dd 2.34 $\mathrm{cmol}_{(+)} / \mathrm{kg}$ tergolong tinggi, K-dd 0.68 $\mathrm{cmol}_{(+)} / \mathrm{kg}$ tergolong tinggi, Na-dd 0.11 $\mathrm{cmol}_{(+)} / \mathrm{kg}$ tergolong rendah, dengan Kejenuhan Basa $16.03 \%$ tergolong sangat rendah, dan Al-dd $1.65 \mathrm{cmol}_{(+)} / \mathrm{kg}$ (Tabel $1)$.

Berdasarkan hasil analisis keragaman pada Tabel 2 menunjukkan bahwa perlakuan jarak tanam berpengaruh nyata sampai sangat nyata terhadap semua peubah yang diamati, namun berpengaruh tidak nyata terhadap jumlah cabang primer. Perlakuan jenis pupuk organik berpengaruh sangat nyata terhadap tinggi tanaman, berat 100 biji dan hasil panen per petak, namun berpengaruh tidak nyata terhadap peubah yang diamati yang lainnya. Sedangkan perlakuan interaksi antara jarak tanam dan jenis pupuk organik berpengaruh tidak nyata terhadap peubah yang diamati yang lainnya.

Hasil uji Beda Nyata Jujur (BNJ) pengaruh perlakuan jarak tanam dan jenis pupuk organik terhadap pertumbuhan, kadar hara NPK dan produksi tanaman kedelai dapat dilihat pada Tabel 3- 5 dan Gambar 1.

Tabel 3 menunjukkan bahwa perlakuan jenis pupuk organik hayati berbeda sangat nyata dengan jenis pupuk organik kotoran sapi terhadap peubah tinggi tanaman, jumlah polong hampa, berat 100 biji dan hasil panen per petak, namun berbeda tidak nyata dengan perlakuan jenis pupuk organik kotoran ayam. Tabel 4 menunjukkan bahwa jarak tanam $20 \times 30 \mathrm{~cm}$ berbeda sangat nyata dengan jarak tanam $20 \times 40$ $\mathrm{cm}$ terhadap semua peubah yang diamati, namun berbeda tidak nyata dengan perlakuan jarak tanam $20 \times 20 \mathrm{~cm}$. Tabel 5 menunjukkan kombinasi perlakuan jarak tanam 20 x $30 \mathrm{~cm}$ dengan jenis pupuk organik hayati mampu memberikan pertumbuhan, kadar hara NPK dan produksi tertinggi pada tanaman kedelai.

\section{Pembahasan}

Hasil analisis tanah sebelum penelitian menunjukkan bahwa kesuburan tanah rendah yang ditunjukkan dengan Kejenuhan Basa (KB) 16,03\%. Kejenuhan Basa $16,03 \%$ memiliki kandungan unsur hara 
$16,03 \%$ sedangkan ion-ion logam $83,97 \%$. Tanah ini dominan memiliki ion-ion logam (seperti Al, Mn, dan Fe) dan apabila terhidrolisis dapat menyumbangkan ion $\mathrm{H}^{+}$ di dalam tanah dan mengakibatkan tanah menjadi masam dan $\mathrm{pH}$ akan semakin rendah. Rendahnya $\mathrm{pH}$ dapat mengakibatkan unsur hara NPK tidak tersedia bagi tanaman, oleh karena itu untuk meningkatkan kandungan unsur hara yang tidak tersedia akibat dijerap oleh ion logam (membentuk Al-P, Fe-P dan Mn-P) dapat diberikan pupuk organik baik itu pupuk organik kotoran ayam, sapi maupun pupuk organik hayati.

Diharapkan dengan pemberian pupuk organik dapat memperbaiki sifat fisika, kimia dan biologi tanah. Menurut Simanungkalit et al. (2006), pupuk organik dapat berperan sebagai pengikat butiran primer menjadi butiran sekunder tanah dalam pembentukan agregat yang mantap. Keadaan ini besar pengaruhnya pada porositas, penyimpanan, penyediaan air, aerase udara dan suhu tanah. Pupuk organik juga berperan sebagai sumber energi dan makanan mikroba tanah, sehingga dapat meningkatkan aktivitas mikroba tersebut dalam penyediaan hara tanaman.

Tanaman kedelai yang diberi pupuk organik hayati memiliki kadar hara $\mathrm{N}$ $(2,28 \%), \mathrm{P}(0,31 \%)$ dan $\mathrm{K}(1,77 \%)$ yang lebih tinggi bila dibandingkan dengan pemberian jenis pupuk organik kotoran sapi $(1,79 \% \mathrm{~N}, 0,24 \% \mathrm{P}, 1,67 \% \mathrm{~K})$ dan ayam $(1,96 \% \mathrm{~N}, 0,27 \% \mathrm{P}, 1,72 \% \mathrm{~K})$. Kadar hara $\mathrm{N}, \mathrm{P}$ dan $\mathrm{K}$ ini dapat dimanfaatkan oleh tanaman kedelai sebagai sumber hara dan dapat digunakan dalam meningkatkan pertumbuhan dan produksi tanaman kedelai. Hal ini sesuai dengan penelitian Sagala et al. (2011), bahwa tanaman kedelai yang dapat menyerap $\mathrm{N}$ lebih banyak dan mampu menggunakan $\mathrm{N}$ secara efisien dan menggunakannya untuk semua komponen tanaman secara merata dari awal pertumbuhan sampai menghasilkan produksi kedelai (seperti jumlah polong yang terbentuk). Selain itu jumlah daun dan jumlah polong yang banyak dapat meningkatkan produktivitas tanaman kedelai. Daun merupakan source utama, polong atau biji merupakan sink utama bagi tanaman kedelai. Tersedianya source dan sink dapat meningkatkan produksi biji.

Pupuk organik hayati ini diperkaya bakteri Azospirillum dan bakteri pelarut fosfat. Bakteri Azospirillum mampu menyediakan unsur hara $\mathrm{N}$ dan $\mathrm{P}$ bagi pertumbuhan (Widawati, 2011b), sebagai bakteri pemantaf agregat tanah (Miharja, 2003), sebagai pupuk hayati yang mampu melarutkan $\mathrm{P}$ terikat oleh $\mathrm{Al}, \mathrm{Ca}$ dan $\mathrm{Fe}$ dalam tanah menjadi unsur $\mathrm{P}$ tersedia bagi tanaman (Widawati, 2011a), mampu menambat $\mathrm{N}_{2}$ dari udara dan mengubahnya menjadi $\mathrm{NH}_{3}$ menggunakan enzim nitrogenase kemudian diubah menjadi glutamin atau alanin (Waters et al., 1998), sehingga bisa diserap oleh tanaman dalam bentuk $\mathrm{NO}_{3}{ }^{-}$dan $\mathrm{NH}_{4}{ }^{+}$. Bakteri Azospirillum ini juga dapat mempengaruhi tanaman cabai yang mampu meningkatkan tinggi tanaman, jumlah daun dan berat buah (Permatasari dan Nurhidayati, 2014).

Sedangkan bakteri pelarut fosfat mampu meningkatkan ketersediaan unsur $\mathrm{P}$ bagi tanaman hingga 50\%. Peningkatan ketersediaan unsur $\mathrm{P}$ ini disebabkan karena mikroba pelarut fosfat mampu mengeluarkan asam-asam organik seperti asam sitrat, glutamate, suksinat, glioksilat yang dapat mengkhelat $\mathrm{Al}, \mathrm{Ca}$ dan $\mathrm{Mg}$ sehingga fosfor yang terikat menjadi larut dan tersedia (Boraste et al., 2009). Unsur P dapat merangsang pembungaan dan pembuahan serta merangsang pembentukan biji kedelai (Subowo et al., 2010).

Bakteri pelarut fosfat juga melarutkan $\mathrm{P}$ terikat oleh $\mathrm{Al}, \mathrm{Ca}$ dan $\mathrm{Fe}$ dalam tanah menjadi unsur $\mathrm{P}$ tersedia bagi tanaman (Widawati, 2011a). Bakteri pelarut fosfat mampu melarutkan $\mathrm{P}$ dari ikatan Seng Fosfat sebesar 30\%, sebesar $19 \%$ dari ikatan Kalsiumfosfat, sebesar $18 \%$ dari ikatan trikalsiumfosfat (Seihadri, 2002), melarutkan $\mathrm{P}$ dari ikatan $\mathrm{Ca}_{2}\left(\mathrm{PO}_{4}\right)_{2} \quad 18,59$ $\mathrm{mg} / \mathrm{L}$, sebesar $18,31 \mathrm{mg} / \mathrm{L}$ dari ikatan $\mathrm{Al}_{2}$ $\left(\mathrm{PO}_{4}\right)_{2}$ dan sebesar $7,4 \mathrm{mg} / \mathrm{L}$ dari rockphosphate (Widawati, 2011a). 


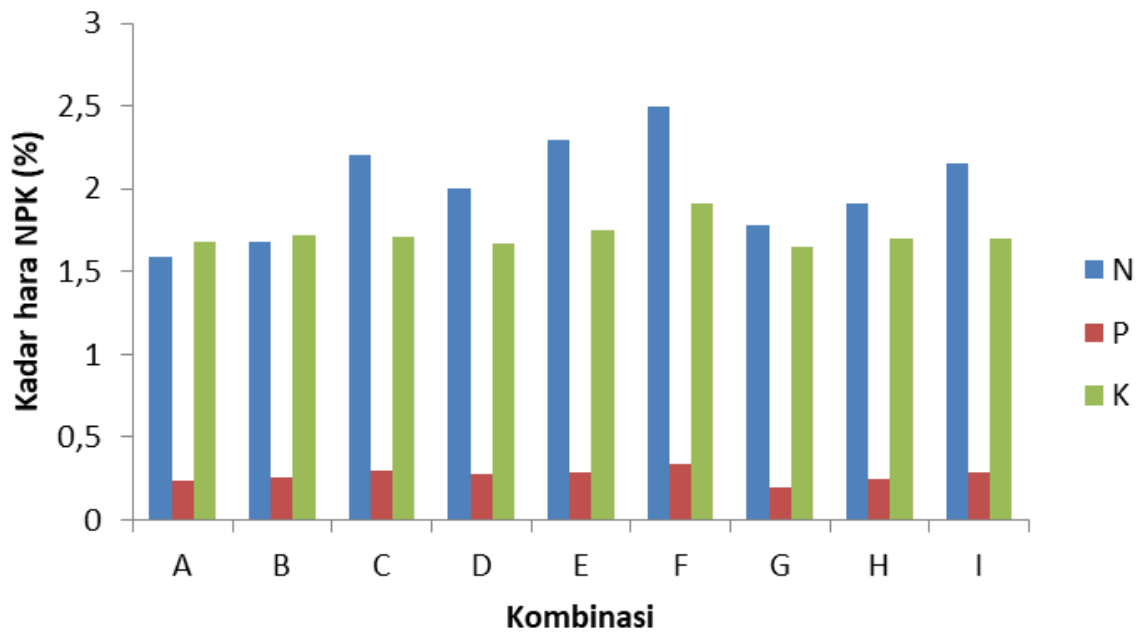

Gambar 1. Kadar hara NPK (\%) pada perlakuan kombinasi jarak tanam dengan pupuk organik

Keterangan: $\mathrm{A}=$ jarak tanam $20 \times 20 \mathrm{~cm}$ dengan kotoran sapi, $\mathrm{B}=$ jarak tanam $20 \times 20 \mathrm{~cm}$ dengan kotoran ayam, $\mathrm{C}=$ jarak tanam $20 \times 20 \mathrm{~cm}$ dengan pupuk organik hayati, $\mathrm{D}=$ jarak tanam $20 \times 30 \mathrm{~cm}$ dengan kotoran sapi, $E=$ jarak tanam $20 \times 30 \mathrm{~cm}$ dengan kotoran ayam, $\mathrm{F}=$ jarak tanam $20 \times 20$ dengan pupuk organik hayati, $\mathrm{G}=$ jarak tanam $20 \times 40 \mathrm{~cm}$ dengan kotoran sapi, $\mathrm{H}=$ jarak tanam $20 \times 40 \mathrm{~cm}$ dengan kotoran ayam, I = jarak tanam $20 \times 40 \mathrm{~cm}$ dengan pupuk organik hayati

Tabel 1. Hasil analisis kimia tanah awal sebelum tanam

\begin{tabular}{|c|c|c|}
\hline Jenis Analisa & Hasil Analisis & Penilaian $^{*}$ \\
\hline $\mathrm{pH} \mathrm{H}_{2} \mathrm{O}(1: 1)$ & 4.23 & Sangat Masam \\
\hline $\mathrm{C} / \mathrm{N}$ ratio & 18.38 & Tinggi \\
\hline C-organik (\%) & 3.83 & Sangat tinggi \\
\hline N-total (\%) & 0.32 & Rendah \\
\hline P Bray I (mg/kg) & 10.42 & Tinggi \\
\hline $\mathrm{Ca}-\mathrm{dd}\left(\mathrm{cmol}_{(+)} / \mathrm{kg}\right)$ & 1.86 & Sangat rendah \\
\hline $\mathrm{Mg}$-dd $\left(\mathrm{cmol}_{(+)} / \mathrm{kg}\right)$ & 2.34 & Sangat tinggi \\
\hline K-dd $\left(\mathrm{cmol}_{(+)} / \mathrm{kg}\right)$ & 0.68 & tinggi \\
\hline $\mathrm{Na}-\mathrm{dd}\left(\mathrm{cmol}_{(+)} / \mathrm{kg}\right)$ & 0.11 & Sangat rendah \\
\hline KTK $\left(\mathrm{cmol}_{(+)} / \mathrm{kg}\right)$ & 25.00 & Tinggi \\
\hline $\mathrm{KB}(\%)$ & 16.03 & Sangat rendah \\
\hline $\mathrm{Al}-\mathrm{dd}\left(\mathrm{cmol}_{(+)} / \mathrm{kg}\right)$ & 1.65 & \\
\hline
\end{tabular}

Keterangan: Hasil analisis Laboratorium di Bina Sawit (2018)

Tabel 2. Hasil analisis keragaman pengaruh jarak tanam dan jenis pupuk organik terhadap peubah yang diamati

\begin{tabular}{|c|c|c|c|c|}
\hline \multirow[t]{2}{*}{ Peubah yang Diamati } & \multicolumn{3}{|c|}{ Perlakuan } & \multirow{2}{*}{$\begin{array}{c}\text { Koefisien } \\
\text { Keragaman }(\%)\end{array}$} \\
\hline & Jarak Tanam & Pupuk Organik & Interaksi & \\
\hline Tinggi tanaman $(\mathrm{cm})$ & $* *$ & $* *$ & $\operatorname{tn}$ & 2.50 \\
\hline Jumlah cabang primer (cabang) & tn & th & tn & 14.51 \\
\hline Jumlah polong per tanaman & & & & \\
\hline 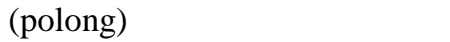 & $* *$ & tn & tn & 3.44 \\
\hline Jumlah polong hampa (polong) & $* *$ & tn & tn & 12.59 \\
\hline Berat 100 biji $(\mathrm{g})$ & $*$ & $* *$ & tn & 2.70 \\
\hline Jumlah biji per polong (buah) & $*$ & tn & tn & 3.93 \\
\hline Kadar hara N $(\%)$ & tn & tn & tn & 30.55 \\
\hline Kadar hara P (\%) & tn & tn & tn & 3.56 \\
\hline Kadar hara K (\%) & tn & tn & tn & 4.11 \\
\hline Hasil panen per petak (g) & $* *$ & $* *$ & tn & 0.79 \\
\hline
\end{tabular}

Keterangan: $\mathrm{tn}=$ berpengaruh tidak nyata, $*=$ berpengaruh nyata, $* *=$ berpengaruh sangat nyata 
Tabel 3. Pengaruh jenis pupuk organik terhadap peubah yang diamati

\begin{tabular}{|c|c|c|c|c|c|c|c|}
\hline $\begin{array}{l}\text { Jenis } \\
\text { Pupuk } \\
\text { Organik }\end{array}$ & $\begin{array}{l}\text { Tinggi } \\
\text { Tanaman } \\
(\mathrm{cm})\end{array}$ & $\begin{array}{l}\text { Jumlah } \\
\text { Cabang } \\
\text { Primer } \\
\text { (Cabang) }\end{array}$ & $\begin{array}{l}\text { Jumlah } \\
\text { Polong } \\
\text { Per } \\
\text { Tanaman } \\
\text { (Polong) }\end{array}$ & $\begin{array}{l}\text { Jumlah } \\
\text { Polong } \\
\text { Hampa } \\
\text { (Polong) }\end{array}$ & $\begin{array}{l}\text { Berat } 100 \\
\text { Biji }(g)\end{array}$ & $\begin{array}{l}\text { Jumlah } \\
\text { Biji Per } \\
\text { Polong } \\
\text { (Buah) }\end{array}$ & $\begin{array}{l}\text { Hasil Panen } \\
\text { Per Petak } \\
\text { (g) }\end{array}$ \\
\hline $\begin{array}{l}\text { Kotoran } \\
\text { sapi }\end{array}$ & $68.26^{\mathrm{a}}$ & 4.25 & 66.39 & $4.33^{b}$ & $\begin{array}{r}10.89^{\mathrm{a}} \\
\mathrm{A}\end{array}$ & 2.61 & $\begin{array}{r}861.69^{a} \\
A\end{array}$ \\
\hline $\begin{array}{l}\text { Kotoran } \\
\text { ayam }\end{array}$ & $68.44_{\mathrm{A}}^{\mathrm{b}}$ & 4.47 & 67.47 & $3.94^{\mathrm{ab}}$ & $\begin{array}{r}11.22_{\mathrm{AB}}^{\mathrm{ab}} \\
\text {. }\end{array}$ & 2.75 & $\begin{array}{r}870.89^{b} \\
A B\end{array}$ \\
\hline $\begin{array}{l}\text { Pupuk } \\
\text { organik } \\
\text { hayati }\end{array}$ & $72.44^{\mathrm{b}}$ & 4.81 & 69.11 & $3.72^{\mathrm{a}}$ & $11.44_{B}^{b}$ & 2.86 & $878.11_{\text {B }}^{\mathrm{b}}$ \\
\hline BNJ $0,05=$ & 2.19 & & & 0.61 & 0.38 & & 8.64 \\
\hline $0,01=$ & 2.93 & $\operatorname{tn}$ & tn & 0.81 & 0.51 & tn & 11.56 \\
\hline
\end{tabular}

Keterangan: Angka-angka yang diikuti oleh huruf yang sama pada kolom yang sama berarti berbeda tidak nyata pada uji BNJ 0,05 (a,b,..) dan 0,01 (A,B ..)

Tabel 4. Pengaruh jarak tanam terhadap peubah yang diamati

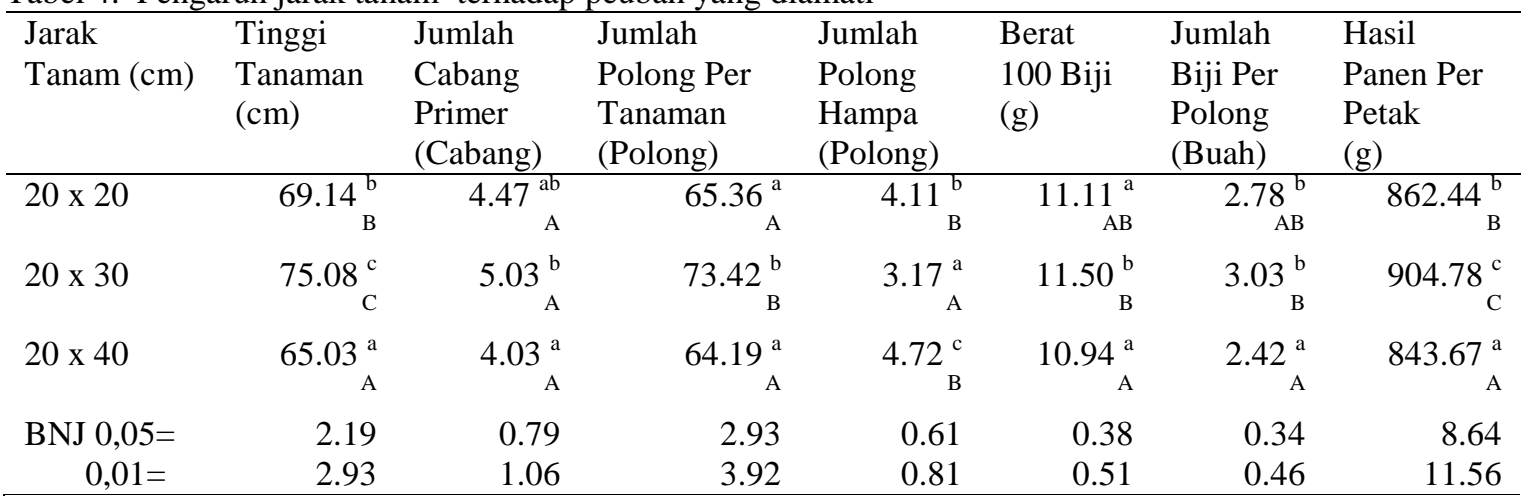

Keterangan: Angka-angka yang diikuti oleh huruf yang sama pada kolom yang sama berarti berbeda tidak nyata pada uji BNJ 0,05 (a,b,..) dan 0,01 (A,B ..)

Bakteri Azospirillum dan bakteri pelarut fofat memberikan pengaruh dalam pertumbuhan tinggi tanaman, jumlah cabang primer, jumlah polong dan biji per tanaman, berat 100 biji serta hasil panen per petak. Unsur hara $\mathrm{N}$ dan $\mathrm{P}$ yang disumbangkan dari keberadaan bakteri Azospirillum dan bakteri pelarut fosfat telah mampu meningkatkan kandungan klorofil dan proses fotosintesis juga meningkat, sehingga asimilat yang dihasilkan lebih banyak akibatnya pertumbuhan dan produksi tanaman kedelai meningkat. Hal ini sejalan dengan pendapat Gusniati et al., 2008: Tanian et al., 2012), bahwa bakteri penambat nitrogen dapat menyumbangkan $\mathrm{N}$ dan mampu meningkatkan kandungan klorofil dan kloroplas pada daun dan proses fotosintesis juga meningkat akibatnya pertumbuhan tanaman lebih baik. Meningkatnya fotosintesis maka akan meningkatkan pertumbuhan dan perpanjangan sel sehingga pertumbuhan tinggi tanaman semakin tinggi.

Kadar hara N (2,28\%), P $(0,31 \%)$ dan $\mathrm{K}(1,77 \%)$ yang terdapat dalam jaringan daun tanaman kedelai yang diberi pupuk organik hayati mendekati kadar hara optimal untuk pertumbuhan tanaman kedelai (2-5\% N, 0,3-0,5\% P, 1,7-2,5\% K). Produksi yang dihasilkan setara 2,43 ton/ha yang hampir mendekati produksi nasional 2,77 ton/ha. Ketersediaan hara $\mathrm{N}$ yang tinggi dalam pemberian pupuk organik hayati ini dapat meningkatkan hasil kedelai. Menurut Basir-Cyio (2004), tanaman kedelai memerlukan serapan hara $\mathrm{P}$ yang tinggi pada fase generatif, karena pada masa ini hara $\mathrm{P}$ diimobilisasi menuju bagian-bagian generatif seperti polong tanaman yang sedang dalam proses pengisian biji. Besarnya serapan $P$ tergantung dari ketersediaan $\mathrm{P}$ dalam 
larutan tanah dan perakaran tanaman. Selanjutnya menurut Djafar, 1984 dalam Supriyadi et al., 2014), berat polong yang tinggi didukung oleh efisiensi serapan P. P sangat dibutuhkan kedelai untuk pertumbuhan biji sehingga suplai $\mathrm{P}$ yang cukup menyebabkan diperolehnya produksi yang memuaskan. Sedangkan unsur K sangat berperan dalam proses pembentukan polong dan polong bernas pada tanaman kedelai.

Perlakuan jenis pupuk organik kotoran sapi memberikan pertumbuhan dan produksi terendah, hal ini disebabkan karena kadar hara $\mathrm{N}, \mathrm{P}$ dan $\mathrm{K}$ yang tersedia lebih rendah bila dibandingkan dengan jenis pupuk organik hayati, sehingga menyebabkan tanaman mengalami kekurangan unsur hara NPK. Menurut Marschner (1995) bahwa apabila tanaman kekurangan unsur hara NPK maka dapat menghambat laju pertumbuhan dan hasil tanaman. Keterbatasan source (kadar hara NPK) dan sink (polong atau biji) dapat menghambat laju pertumbuhan dan hasil. Source yang lemah (sedikit) akan menyebabkan semakin lambat, sebaliknya apabila source kuat (banyak) namun sink lemah juga dapat menyebabkan produksi biji yang didapat rendah.

Tabel 5. Pengaruh kombinasi antara jarak tanam dan jenis pupuk organik terhadap peubah yang diamati

\begin{tabular}{|c|c|c|c|}
\hline $\begin{array}{l}\text { Jarak Tanam } \\
(\mathrm{cm})\end{array}$ & Kotoran Sapi & $\begin{array}{c}\text { Jenis Pupuk Organ } \\
\text { Kotoran Ayam }\end{array}$ & Pupuk Organik Hayati \\
\hline \multicolumn{4}{|c|}{ Tinggi Tanaman $(\mathrm{cm})$} \\
\hline $20 \times 20$ & 67.00 & 67.17 & 73.25 \\
\hline $20 \times 30$ & 73.75 & 73.75 & 77.75 \\
\hline $20 \times 40$ & 64.33 & 64.42 & 66.33 \\
\hline \multicolumn{4}{|c|}{ Jumlah Cabang Primer (Cabang) } \\
\hline $20 \times 20$ & 4.33 & 4.67 & 4.42 \\
\hline $20 \times 30$ & 4.58 & 4.83 & 5.67 \\
\hline $20 \times 40$ & 3.83 & 3.92 & 4.33 \\
\hline \multicolumn{4}{|c|}{ Jumlah Polong Per Tanaman (Polong) } \\
\hline $20 \times 20$ & 64.50 & 64.70 & 66.92 \\
\hline $20 \times 30$ & 72.17 & 73.75 & 74.33 \\
\hline $20 \times 40$ & 62.50 & 64.00 & 66.08 \\
\hline \multicolumn{4}{|c|}{ Jumlah Polong Hampa (Polong) } \\
\hline $20 \times 20$ & 4.67 & 3.92 & 3.75 \\
\hline $20 \times 30$ & 3.33 & 3.17 & 3.00 \\
\hline $20 \times 40$ & 5.00 & 4.75 & 4.42 \\
\hline \multicolumn{4}{|c|}{ Jumlah Biji Per Polong (Buah) } \\
\hline $20 \times 20$ & 2.67 & 2.83 & 2.83 \\
\hline $20 \times 30$ & 2.92 & 3.00 & 3.17 \\
\hline $20 \times 40$ & 2.25 & 2.42 & 2.58 \\
\hline \multicolumn{4}{|c|}{ Berat 100 Biji (g) } \\
\hline $20 \times 20$ & 10,75 & 11,17 & 11,42 \\
\hline $20 \times 30$ & 11,33 & 11,50 & 77,75 \\
\hline $20 \times 40$ & 10,58 & 11,00 & 11,25 \\
\hline \multicolumn{4}{|c|}{ Hasil Panen Per Petak (g) } \\
\hline $20 \times 20$ & 856,33 & 859,33 & 871,67 \\
\hline $20 \times 30$ & 896,00 & 907,00 & 911,33 \\
\hline $20 \times 40$ & 833,33 & 846,33 & 851,33 \\
\hline
\end{tabular}

Jarak tanam $20 \mathrm{~cm} \quad$ x $30 \mathrm{~cm}$ pada tanaman kedelai telah mampu meningkatkan produksinya, hal ini menunjukkan bahwa jarak tanam $20 \mathrm{~cm}$ x $30 \mathrm{~cm}$ merupakan jarak tanam yang ideal bagi tanaman kedelai yang ditanam di lahan pasang surut tipe luapan C ini. Selain itu didukung oleh kadar hara $\mathrm{N}(2,27 \%)$, $\mathrm{P}$ $(0,30 \%)$ dan $\mathrm{K}(1,78 \%)$ yang lebih banyak bila dibandingkan dengan dengan kadar hara NPK $(1,94 \% \mathrm{~N}, 0,27 \% \mathrm{P}$, dan $1,70 \%$ $\mathrm{K})$ pada jarak tanam $20 \mathrm{~cm}$ x $20 \mathrm{~cm}$ dan dan $20 \mathrm{~cm}$ x $40 \mathrm{~cm}(1,94 \% \mathrm{~N}, 0,25 \mathrm{P}$ dan $1,68 \%$ K). Ini berarti jarak tanam $20 \mathrm{~cm}$ x $30 \mathrm{~cm}$ 
dapat memperkecil terjadinya kompetisi unsur hara bagi tanaman, dan unsur hara yang ada dapat dimanfaatkan oleh tanaman kedelai untuk tumbuh dan berproduksi dengan baik. Hal ini sesuai dengan pendapat Harjadi (1991) bahwa jarak tanam yang ideal bagi tanaman akan memperkecil kompetisi bagi tanaman, sehingga dapat memberikan hasil yang optimum. Selanjutnya ditambahkan oleh Barus (2004), bahwa jarak tanam yang tepat dapat meningkatkan pertumbuhan tanaman. Jarak tanam $20 \mathrm{~cm} \quad x \quad 30 \mathrm{~cm}$ ini mampu meningkatkan jumlah cabang primer yang terbentuk. Hal ini disebabkan karena jarak tanam ini dapat memanfaatkan sinar matahari untuk proses fotosintesis sehingga dapat meningkatkan pertumbuhan tanaman. Sedangkan jarak tanam $20 \mathrm{~cm}$ x $20 \mathrm{~cm}$ dan $20 \mathrm{~cm} \times 40 \mathrm{~cm}$ memberikan pertumbuhan dan produksi yang rendah, hal ini menunjukkan bahwa jarak tanam yang rapat dan lebar sangat menghambat pertumbuhan dan produksi tanaman kedelai. Menurut Susilo (2004), bahwa jarak tanam yang tidak sesuai maka akan terjadi kompetisi yang bersifat merugikan tanaman. Selanjutnya Marliah et al. (2012), penggunaan jarak tanam yang rapat dapat mempengaruhi persaingan dalam penggunaan cahaya matahari dan unsur hara. Sedangkan Sohel (2009) dalam Hatta (2012), jarak tanam yang terlalu lebar berpotensi menjadi tidak produktif. Banyak bagian lahan menjadi tidak termanfaatkan oleh tanaman sehingga banyak terdapat ruang kosong. Kombinasi antara jarak tanam $20 \mathrm{~cm} \mathrm{x} 30 \mathrm{~cm}$ dengan jenis pupuk organik hayati $400 \mathrm{~kg} / \mathrm{ha}$ memberikan pertumbuhan dan produksi yang lebih tinggi bila dibandingkan dengan perlakuan kombinasi yang lainnya. Hal ini disebabkan dengan jarak tanam $20 \mathrm{~cm} \quad$ x $30 \mathrm{~cm}$ merupakan jarak tanam yang ideal bagi tanaman kedelai dan mampu memberikan ruang bagi tanaman menerima cahaya matahari dalam memperlancar proses fotosintesis yang bahan baku berasal dari unsur hara dari pupuk organik hayati, sehingga hasil fotosintat dapat digunakan untuk meningkatkan pertumbuhan dan produksi tanaman kedelai dengan hasil panen per petak 911, $33 \mathrm{~g} /$ petak atau setara 2,43 ton/ha. Sedangkan produksi nasional kedelai 2,77 ton/ha. Hal ini menunjukkan bahwa jenis pupuk organik hayati dengan takaran $400 \mathrm{~kg} / \mathrm{ha}$ dengan jarak tanam 20 $\mathrm{cm}$ x $30 \mathrm{~cm}$ dapat direkomendasikan untuk tanaman kedelai di lahan pasang surut tipe luapan C.

\section{KESIMPULAN}

Perlakuan kombinasi antara jarak tanam $20 \mathrm{~cm} \times 30 \mathrm{~cm}$ dengan jenis pupuk organik hayati $400 \mathrm{~kg} / \mathrm{ha}$ mampu meningkatkan produksi kedelai 9,11 g/petak atau setara dengan 2,43 ton/ha.

\section{UCAPAN TERIMAKASIH}

Penulis mengucapkan terima kasih kepada Kementerian Riset, teknologi dan Pendidikan Tinggi Direktorat Jenderal Penguatan Riset dan Pengembangan yang membiayai kegiatan ini melalui Penelitian Hibah Bersaing Tahun 2 Tahun Anggaran 2017 dengan surat Perjanjian Penugasan Pelaksanaan Program Penelitian Nomor: 2611/SP2H/K2/KM/2017, tanggal 10 April 2017, dan kepada Agus Priyanto yang telah banyak membantu di lapangan.

\section{DAFTAR PUSTAKA}

Barus WA. 2004. Respon pertumbuhan dan hasil kedelai yang ditumpangsarikan dengan jagung terhadap pengaturam saat tanam dan jarak tanam. http://repository.usu.ac.id/bitstream/hand le/123456789/15513/kpt-des2004$\% 20 \% 282 \% 29$.pdf? sequence $=1 \&$ is Allowed $=y$ [Diakses 26 Januari 2017].

Boraste A, Vansi KK, Jhadav A, Khaimar Y, Gupta N, Trivedi S, Patil P, Gupta G, Gufta M, Mujapara AK, Joshi B. 2009. Biofertilizer a Nove; too; for agriculture. International Hourmal of Microbiology Research. 1:23-31. 
Basir-Cyio M. 2004. Aplikasi indeks biokimia dalam penentuan karakteristik dan kesuburan tanah yang diberi bahan organik terinkubasi. J. Agroland. 11(1):65-72.

Detik Finance. 2013. Produksi Kedelai Republik Indonesia Rendah. Koran terbit 25 Juli 2013

Gusniati N, Fatian ME, Arief R. 2008. Pertumbuhan dan hasil tanaman jagung dengan pemberian kompos alang-alang. Jurnal Agronomi. 12(2):23-27.

Harjadi MM. 1991. Pengantar Agronomi. Jakarta; Gramedia

Hatta M. 2012. Pengaruh karak tanam heksagonal terhadap pertumbuhan dan hasil tiga varietas padi. Jurnal Floratek. 7:151-156.

Hidayat N. 2008. Pertumbuhan dan produksi kacang tanah (Arachis hypogeae L.) varietas lokal Madura pada berbagai jarak tanam dan pupuk fosfor. Agroviva. 1(1):53-63

Hutahean L, Ananto E, Raharjo B. 2019. Pengembangan teknologi pertanian lahan pasang surut dalam mendukung peningkatan produksi pangan (Kasus di Sumsel) in Buku Pembangunan Pertanian Berbasis Ekoaegion. Badan Penelitian Pengembangan Pertanian, Jakarta Selatan.

Marliah A, Hidayat T, Husna N. 2012. Pengaruh varietas dan jarak tanam terhadap pertumbuhan kedelai (Glycine $\max$ L. Merril). Jurnal Agrista. 16(1):57.

Marlina N, Aminah RIS, Rosmiah, Setel LR. 2015. Aplikasi pupuk kandang kotoran ayam pada tanaman kacang tanah (Arachis hypogeae L.). Jurnal of Biology and Biology Education. 7(2):138-141.

Marlina N, Rompas JP, Marlina, Musbik. 2017. Nutrient uptake of NPK and result of some rice varietis in tidal land by using combination of organic and inorganic fertilizer. AIP Conference Proceeding. American Institute of Physics 020309-1-8.
Marlina N, Amir N, Palmasari B. 2018. Pemanfaatan berbagai jenis pupuk teradap produksi bawang merah (Allium ascalonicum L.) di tanah pasang surut tipe luapan C asal Banyuurip. Jurnal Lahan Suboptimal. 7(1):74-79.

Marschner H. 1995. Mineral Nutrition of Higher Plants. Academic Press. London; Harcourt Brace Jovanovich Publishers. 889 p.

Miharja OAA. 2003. Peningkatan pertumbuhan dan hasil kedelai serta efisiensi pemupukan fosfat sebagai akibat pemberian pupuk hayati pada tanah ultisol Jatinagor. Kultivasi. 2(3):46-52.

Permatasari AD, Nurhidayati T. 2014. Pengaruh inokulan Bakteri penambat N, bakteri pelarut fosfat dan mikoriza asal desa Condro, Lumajang Jakarta Timur terhadap pertumbuhan tanaman cabai rawit. Jurnal Sains dan Seni Pomits. 3(2):2337-3520.

Sagala D, Ghulamahdi M, Melati M. 2011. Pola serapan hara dan pertumbuhan beberapa varietas kedelai dengan budidaya jenuh air di lahan pasang surut. Jurnal Agroqua. 9(1):1-10.

Simanungkalit RDM, Suriadikarta DA, Saraswati R, Setyorini D, Hartatik W. 2006. Pupuk organik dan pupuk hayati. Balai Besar Penelitian dan Pengembangan Sumberdaya Lahan Pertanian. Bogor. 312 hal.

Subowo YB, Sugiharto W, Suliasih, Widawati S. 2010. Pengujian pupuk hayati Kalbar untuk meningkatkan produktivitas tanaman kedelai (Glycine max L.) varietas Baluran. Jurnal Cakra Tan.i 25:112-118.

Supriyadi S, Hartati, Aminudin A. 2014. Kajian pemberian pupuk $\mathrm{P}$, pupuk mikro dan pupuk organik terhadap serapan $\mathrm{P}$ dan hasil kedelai (Glycine max L.) varietas Kaba di Inceptisol Gunung Gajah Klaten. Cakra Tani-Jurnal ilmuilmu Pertanian. XXIX(2):81-86. 
Susilo E. 2004. Penerapan sistem budidaya dan cara pengendalian gulma pada kedelai (Glycine $m x$ L. Merril) dan Padi (Oryza sativa L.) dalam pola tumpangsari. [Tesis]. Sekolah Pascasarjana IPB. Bogor.

Suriadikarta DA, Sutriadi MT. 2007. Jenis-jenis lahan berpotensi untuk pengembangan pertanian di lahan rawa. Jurnal Litbang Pertanian. 36(3):115122.

Sutrisno. 2004. Studi dosis pupuk dan jarak tanam pada kacang tanah (Arachis hypogeae L.). Laporan Penelitian. Kantor Penelitian dan Pengembangan Kabupaten Pati.

Tanian N, Astini, Bandi S. 2012. Pengaruh pemberian pupuk mikoriza terhadap pertumbuhan dan hasil jagung semi pada tanah Podsolik Merah Kuning. Jurnal Sains Mahasiswa Pertanian. 1(1):10-15. Waters T, Hughes H, Purecell BL, Gerhardt LC, Mowhinney KO, Emerich. DW. 1998. Alanin, not ammonia is excreted from $\mathrm{N}_{2}$-fixing soybean nodule bacteroid. Proc. Natt Acad Sci USA. 95:12038-12042.

Widawati S. 2011a. Diversity and phosphate solubilization by bacteria isolated from Laki Islam Constal ecosyste. Biodiversitas J. Biol Diversity. 12(1):17-21.

Widawati S. 2011b. The role of phosphate solubilizing bacteria and freeliving nitrogen fixing bacteria on the growth and adaption of Gmelina arborea Roxb Grown on degraded land. J. Environ Engineery. 7(1):89-95. 